THE DEMISE OF THE DOMESTIC GANDER

Birds of the Elbow by J. Frank Roy contains a story about a domestic Toulouse $X$ Brown Chinese gander that for eight years helped a pair of Canada Geese raise their young on my farm. In the spring of 1996 this gander was killed in a rather unorthodox way I will try to describe.

Just at dusk on 14 April while doing my chores I noticed a female domestic goose coming to the corrals from a southerly direction. She walked painfully and slowly, her head and neck red with blood. I picked her up and put her in a pen, but when I checked an hour later, she had died. Counting the remaining geese, I found that two more were missing from the flock.

Next morning, at daybreak, I walked south in the direction the goose had come from, and found the spot where coyotes or foxes had ambushed the geese, some 200 yards from the barn in a stubble field behind a shelterbelt. The only signs were feathers strewn about. Across the fence was a bare summerfallow field, where signs of a goose being dragged were quite visible, together with the footprints of a coyote or fox. The track soon reached grassland and was no longer visible. At the bottom of a nearby draw was an icecovered dam; on it lay a goose, obviously still alive, its head and neck covered with blood.

Uncertain whether the ice would be safe to walk upon, I decided to leave the goose for the time being and went home for breakfast. Later, I returned to the dam. By then the goose had moved over near the north shore and I managed to head it in the direction of home. I recognized him now as the gander that associated with the Canadas.

He had trouble seeing out of one eye but was not hard to get to the barn, where I captured him and examined his wounds. There were punctures in the head and neck, as with the female that had died, a bare spot the size of a dime on his skull, and one eye clouded with matter. I first contemplated putting him down, but he took readily to food and water offered him, so I put him in a box stall. He recovered quite well, even to seeing with both eyes, and three weeks later I released him.

By this time the pair of Canadas that he always associated with had returned from the south and the female was spending most of her time on the nest. Wasting no time with the other domestic geese in the farmyard, the gander soon joined the wild pair. $\mathrm{He}$ and the Canada gander generally swam side by side. When I brought grain down each morning, the domestic goose would come to meet me, the Canada not far behind. The two would stand side by side while feeding.

On the morning of 11 May I again brought food down. The Canada was at the north end of the dam and the domestic at the south end. It was the same the next morning, with neither coming to feed. There had apparently been a rift in their friendship. That day, the domestic came up to the farmyard where my son Darryl saw and heard domestic ganders having a battle. When I went over to where they had fought, I found the domestic goose lying dead. The bare spot on his skull was now the size of a quarter and I wondered if a blow on the head could have killed him. Ganders fight by grabbing their opponent 
had revealed no traces of the bird. Apparently the drag marks were those of the gander, but it seemed impossible that a coyote or fox could capture a goose, drag it for 100 yards or more, and then let it get away on the ice of a dam, which would safely hold up an animal. The only explanation I can give is that our dog Shep must have heard the commotion and driven the predator away. He is ever watchful of coyotes and foxes and even pursues hawks and owls when they come close. On one occasion he chased foxes away after they had injured two geese. Another time a fox had captured a turkey gobbler, torn out a mass of feathers and injured it so badly it had to be destroyed; tracks in the snow showed the fox had fled in haste.

- SIG JORDHEIM, P.O. Box 544, Kyle, SK SOL 1 TO

\section{COURTSHIP BEHAVIOUR OF A PAIR OF BLACK-BILLED MAGPIES}

On 2 March 1997, a cloudy, but bright, windless day, I had left Moose Jaw, Saskatchewan, about 4 p.m. and at the Hwy. \#1 sign permitting motorists a speed of $100 \mathrm{kph}, \mathrm{I}$ set the cruise control when that speed was reached. I maintained that speed when I reached the start of the area which, many years ago, was separate sand and gravel pits. My odometer read $1.8 \mathrm{k}$ when I arrived at the point where the road levelled off, as it had climbed a little. At the same time I saw, almost straight ahead, but somewhat to my right and, perhaps, ten or twelve feet in the air, two Black-billed Magpies (Pica pica), performing the strangest rites I have ever seen.

The two birds were facing each other, only a few inches apart, up- right, with their wings beating slowly, just sufficient to keep them airborne, and their tails were fanned. Their bills were open, but I could not hear anything as the car windows were closed. Because of their relative position to me, I was able to maintain speed, steer properly and still keep my eyes on the birds, so I know that they continued this nuptial performance until I passed them. I watched them for half a minute, maybe 45 seconds. The birds were so engrossed with each other that they took no notice of the car.

In my opinion, their behaviour could have only one possible result copulation.

I described the above to my friend, Fred Lahrman, retired employee of the Royal Saskatchewan Museum in Regina, who told me that he owned a copy of Arthur Cleveland Bent's "Life Histories of North American Crows, Jays and Titmice" (1947) when I had coffee with him on 4 March. Next day, he told me that the Magpie's courtship behaviour had been seen and described only in "bits and pieces." He emphasized that was how it was described when I questioned the phrase.

I offer the above as the complete performance.

Footnote: On Monday, 5 March 1990 , a cold $\left(15^{\circ} \mathrm{F}\right.$ at $7: 00$ a.m.) bright day I walked, after breakfast, in Wascana, where I saw five Magpies, one of which actually sang an attractive, melodious warble. Fred Lahrman told me that he, too, has heard them sing.

- FRANK H. BRAZIER, 2657 Cameron Street, Regina, SK S4T 2W5 